\title{
Physiological, morphological and biochemical characteristics of the sexual propagation of Piper aduncum (Piperaceae)
}

\author{
SARA DOUSSEAU ${ }^{1,2}$, AMAURI ALVES DE ALVARENGA ${ }^{1}$, EDUARDO ALVES ${ }^{1}$, IZABEL DE \\ SOUZA CHAVES ${ }^{1}$, ELMA DOS SANTOS SOUZA ${ }^{1}$ and JULIANA DA SILVA ALVES ${ }^{1}$
}

(received: October 18, 2010; accepted: April 11, 2011)

\begin{abstract}
Physiological, morphological and biochemical characteristics of the sexual propagation of Piper aduncum (Piperaceae)). In this work we attempted to characterize the diaspores and the germination process of Piper aduncum L., as well as to verify the influence of the interaction between presence and absence of light (photoperiod of 12 hours and dark) and temperature $\left(25^{\circ} \mathrm{C}, 30^{\circ} \mathrm{C}\right.$ and $\left.20-30{ }^{\circ} \mathrm{C}\right)$ and also of gibberellin $\left(0,50,100,200\right.$ and $\left.400 \mathrm{mg} \mathrm{L}^{-1}\right)$ on the root protrusion and normal seedlings formation. The diaspores are very small with a thousand seed weight of $0.3645 \mathrm{~g}, 13 \%$ moisture and protein reserve. Diaspores are strict positively photoblastic in the tested temperature range and the optimum temperature for root protrusion was $30^{\circ} \mathrm{C}$, while for normal seedlings was $25^{\circ} \mathrm{C}$. The previous permanence in the dark led to an increase in the speed of root protrusion and percentage and speed of seedling formation. The application of gibberellic acid negatively interfered with the protrusion and growth of the radicle while favoring the elongation of hypocotyls.
\end{abstract}

Key words - germination, gibberellin, light, post-germination, temperature

RESUMO - (Características fisiológicas, morfológicas e bioquímicas da propagação sexual de Piper aduncum (Piperaceae)). Buscou-se neste trabalho efetuar a caracterização dos diásporos maduros e do processo germinativo de Piper aduncum L., bem como verificar a influência da interação entre presença e ausência de luz (fotoperíodo de 12 horas e escuro) e temperaturas $\left(25^{\circ} \mathrm{C}, 30^{\circ} \mathrm{C}\right.$ e $\left.20-30{ }^{\circ} \mathrm{C}\right)$ e do ácido giberélico $\left(0,50,100,200\right.$ e $\left.400 \mathrm{mg} \mathrm{L}^{-1}\right)$ sobre a germinabilidade e o vigor, considerando a protrusão radicular e as plântulas normais. Os diásporos são diminutos com peso de $0,3645 \mathrm{~g}$ para mil sementes, $13 \%$ de umidade e reserva protéica. São fotoblásticos positivos estritos, na faixa de temperatura testada e a temperatura ótima para a protrusão radicular foi $30^{\circ} \mathrm{C}$, enquanto que para a formação de plântulas normais foi $25^{\circ} \mathrm{C}$. A prévia permanência no escuro levou a um aumento na velocidade de protrusão radicular, e, principalmente, a porcentagem e velocidade de formação de plântulas foram favorecidas. A aplicação de ácido giberélico influenciou negativamente na protrusão e no crescimento da radícula e favoreceu o alongamento do hipocótilo.

Palavras-chave - germinação, giberelina, luz, pós-germinação, temperatura

\section{Introduction}

Piper aduncum L., known as pimenta de macaco, is a shrub native to tropical America and widely distributed across the Brazilian territory, mostly in pastures and forest borders (Lorenzi \& Matos 2002). The species has the potential to be used in the recovery of degraded areas (Alvarenga et al. 2006), and from its shoots an essential oil is extracted, with a promising use both in agriculture and in medicine, given its low toxicity to mammals (Souza et al. 2008). It also posses insecticide activity (Fidalgo et al. 2004, Fazolin et al. 2005, Fazolin et al. 2007, Pereira et al. 2008) and fungicide (Bastos \& Albuquerque 2004, Navickiene et al. 2006, Guerrini et al. 2009).

Knowledge of the germination process and of the seedling, involving morphological and anatomical

\footnotetext{
1. Universidade Federal de Lavras - UFLA, Campus Universitário, Caixa Postal 3037, 37200-000 Lavras, Minas Gerais, Brazil.

2. Autor para correspondência: saradousseau@yahoo.com.br
}

features is of essential importance for taxonomic, ecological and agronomic studies. Moreover, in taxonomy, it may enable the understanding of the phylogeny and of the evolution trends of these structures (Silva et al. 2003). The structure for the dispersal (diaspores) of this species is a small fruit, drupe type, which is formed in infructescences of varying size (Vianna \& Akisue 1997). Morpho-anatomical characterization studies of the diaspores of species of the genus Piper are scarce, most of them summarized in the works of Vianna \& Akisue (1997) for P. aduncum and Rosa \& Souza (2004) for Piper amalago var. medium L., both using only light microscopy.

The chemical composition of seeds is genetically defined, although it may, to some extent, be influenced by environmental conditions to which the plants were submitted (Fait et al. 2006). Knowledge of the chemical composition is of practical interest for seed technology, since both the vigor and storage longevity may be influenced by compounds in the seeds (Carvalho \& Nakagawa 2000). To date, there is no information 
in the literature about the chemical composition of the diaspores of Piperaceae species.

Temperature and light are the most significant environmental factors in promoting seed germination in the soil when water is available (Socolowski et al. 2008). Light is a critical regulator of germination in small seeds (Milberg et al. 2000, Pearson et al. 2003, Seo et al. 2009). Light sensitivity of seeds is dependent on the action of phytochromes and change their sensitivity as a function of temperature (Heschel et al. 2007, Franklin 2009). Phytochromes belong to a class of photoreceptors that modulate endogenous levels of gibberellin (GA) and abscisic acid (ABA) and also the responsiveness to GA (Seo et al. 2009). Temperature alters the growth potential of the embryo, and also influences hormone levels. At high temperatures, termo-inhibition may occur due to induction of ABA synthesis and repression of GA (Toh et al. 2008) and in addition the growth potential of the embryo is markedly reduced (Nonogaki 2006). On the other hand, endogenous levels of GA are increased at low temperatures (Penfield 2008, Yamaguchi 2008). Thus, there is a relationship between requirement for light, temperature and levels of GA (Seo et al. 2009). $\mathrm{GA}_{3}$ solutions are recommended according to Brasil (2009a) in routine analysis, in the concentration of $200 \mathrm{mg} \mathrm{L}^{-1}$ and $500 \mathrm{mg} \mathrm{L}^{-1}$ for seeds with dormancy.

According to Rocha et al. (2005), the seeds of $P$. aduncum are positively photoblastic, not germinating in the absence of light. However, little is known about the influence of temperature on the germination of Piperaceae, and to date there are no studies dealing with its interaction with light. For $P$. aduncum, diaspores submitted to germination at $24^{\circ} \mathrm{C}, 27^{\circ} \mathrm{C}$ and $30^{\circ} \mathrm{C}$ did not differ in percentage and germination speed (Silva et al. 2007).

Given the above, we attempted in this work to study the morphological, anatomical and biochemical characteristics of mature $P$. aduncum diaspores, as well as to make a morphological characterization of germination until seedling formation in order to provide information for taxonomic, ecological and agronomic studies. Additionally, some physiological characteristics of drupes submitted to different thermal and light conditions and concentrations of gibberellin were evaluated.

\section{Material and methods}

The species was identified by Dr. Elsie Franklin Guimarães, and the specimen deposited as a voucher in the Herbarium of the Universidade Federal de Lavras, Brazil, under registration number 20275. The fruits were collected from selected matrix plants located in the micro-region of Lavras, Brazil, from October 2007 to February 2008. In lab conditions, fruit processing was performed by washing them with running water in a sieve, and then drying them on filter paper for 12 hours (temperature $25^{\circ} \mathrm{C}$ to $30^{\circ} \mathrm{C}$ ). The moisture content was determined by the stove method at $105{ }^{\circ} \mathrm{C} \pm 3{ }^{\circ} \mathrm{C}$ for 24 hours, using three replicates of $0.1 \mathrm{~g}$ of processed drupes, after dried for 12 hours on a bench. The results were expressed as percentages on a wet basis (Brasil 2009a).

Chemical analyses were performed at the Department of Food Science of the Universidade Federal de Lavras - UFLA, using $2 \mathrm{~g}$ of diaspores pulverized in chilled grinder. The ether extract was determined by extraction in Soxhlet apparatus continues. The defatted powder obtained was submitted to the chemical characterization, according to official methods of AOAC (1990): to quantify the levels of carbohydrates (total reducing sugars, glucose, sucrose and starch) we have used the method of Somogy modified by Nelson (1944); to determine the total nitrogen level, by the method of micro-Kjeldahl, applying the 6.25 factor to calculate the gross protein content; for polyphenols (tannins), we used the method of Folin-Denis.

The weight of a thousand seeds (WTS) was determined following Brasil (2009a), with eight repetitions of 100 seeds in duplicate, the results being expresses in grams (g). We have also calculated the variance, standard deviation and coefficient of variation (CV).

For the morphological characterization of the drupes, we analyzed the color, surfaces, shape and contour of 100 units, with the aid of a stereoscopic microscope. The descriptions of the morphological characteristics were based on Vianna \& Akisue (1997), Aquila (2004), Cocucci \& Mariath (2004) and Brasil (2009b).

Anatomical characterization was performed at the Laboratory of Electron Microscopy and Ultra-structural Analysis of the Universidade Federal de Lavras. We analyzed 50 diaspores, which were fixed and prepared by usual proceedings in scanning electron microscopy, described by Justo et al. (2007). For observation of internal structures, the seeds were frozen in liquid nitrogen, sectioned longitudinally, according to Alves (2004), and observed under a Scanning Electron Microscope.

To monitor the germination stages, four repetitions of 50 diaspores were seeded on the blotting paper substrate, in a Mangelsdorf germinator, at $25^{\circ} \mathrm{C}$ in continuous light and $100 \%$ relative humidity. For the morphological description, we used criteria based on Brasil (2009b) and Aquila (2004). To assess the influence of temperature and light on germination, the drupes were sterilized with $1 \%$ cercobin during 5 minutes and spread on blotting paper, moistened 2.5 times the weight of the paper and packed in acrylic boxes, type gerbox (Brasil 2009a). We evaluated three thermal regimes $\left(25^{\circ} \mathrm{C}, 30^{\circ} \mathrm{C}\right.$ and $20-30{ }^{\circ} \mathrm{C}$ ) under photoperiod of 12 hours and dark, kept in a germination chamber Model BOD 347 Fanem, with relative humidity around $65 \%$. To simulate dark condition, 
the gerboxes were wrapped in aluminum foil and then in black polyethylene bags and the assessment carried out under green light. After staying in total darkness, as there was no root protrusion, the seeds were transferred to light, in the same thermal regime.

For the study of GA, the diaspores were seeded on paper saturated with a solution of $\mathrm{GA}_{3}$ (Brasil 2009a) at $0,50,100,200$ e $400 \mathrm{mg} \mathrm{L}^{-1}$, and germinated at $25^{\circ} \mathrm{C}$, in the presence and absence of light, in the same conditions described above.

The experiment was conducted in a completely randomized design (CRD) with four replications of 100 seeds each, in a $3 \times 2$ factorial, being, temperatures, presence and absence of light. Assessments of germination were carried out daily, and the parameter used was the protrusion $\geq 1 \mathrm{~mm}$ of radicle. We calculated the germination $(\% \mathrm{G})$ and the index of germination speed (IGS), according to Maguire (1962). Statistical analysis was performed with the aid of the statistical software SISVAR (Ferreira, 1999), being performed an analysis of variance and the means compared by the Tukey test $(P<0.05)$.

\section{Results and discussion}

The drupes shape tends to be conical, with its contour obovoid to globular (figures 1 and 4), with depressed ends, $1.15 \pm 0.018 \mathrm{~mm}$ in length, $0.95 \pm 0.087 \mathrm{~mm}$ wide and $0.75 \pm 0.079 \mathrm{~mm}$ thick. The WTS was $0.3645 \mathrm{~g}$. The color of mature diaspores is uniform, black and slightly silver. Many aborted fruits occurred in the infrutescences, with a reddish color, that is intensified with soaking after sowing. A deep cylindrical shape depression, which reach slightly less than $1 / 3$ of the drupe could be seen in the diaspores, of the proximal region to the axis of the inflorescence (figures 2 and 3 ). Probably, that is a linear hilum, due to its position in relation to the axis of inflorescence. In the distal region, it can be observed a porous region could be observed (figure 5) that often contains residuals of the transmitter tissue (figure 1, arrow). As denominated by Oliveira et al. (2008), for Peperomia parnassifolia Miq., this region is probably the micropyle. The hilum (figures 2 and 3 ) and micropyle (figure 5) are visible and opposite, and the seeds are orthotropic. The embryo is small and is located in the distal axis of infructescenses (figure 4). These characteristics were first reported by Vianna \& Akisue (1997), and are markedly characteristics among the species of Piperaceae, as occur in P. amalago var. medium L. (Rosa \& Souza 2004) and P. parnassifolia (Oliveira et al. 2008). At the time of dispersal, the embryo is in the first stadium of development, called trapezoidal stadium, with the visualization of the cotyledons differentiation poles (figure 4). However, Piper amalago var. medium
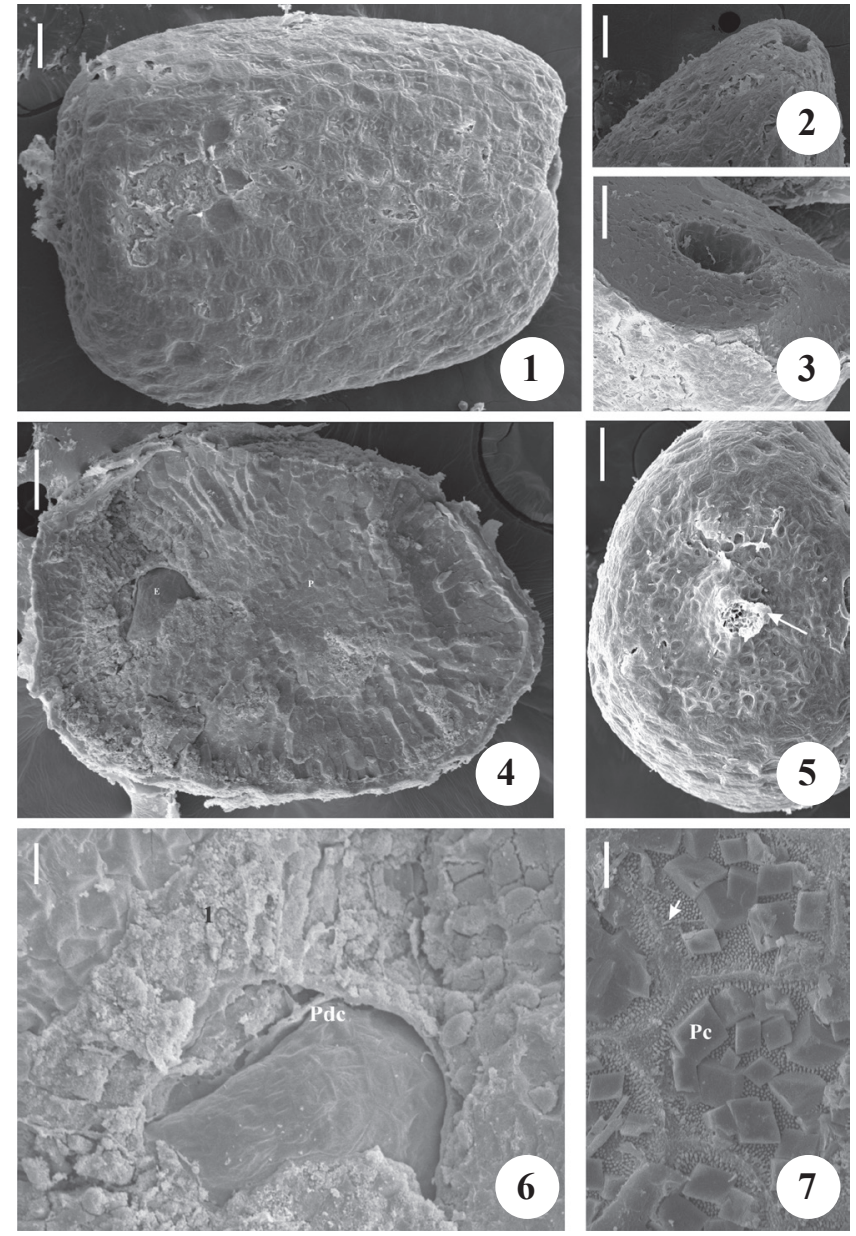

Figures 1-7. Photography (1) and scanning electron micrographs (2-7), characterizing the structure of dispersal of Piper aduncum. 1. Overview of the surface of the diaspores. 2. Detail of the proximal region of the fruit axis (hilum) (arrow). 3. Cross section $1 / 3$ below the proximal region, showing the deep hilum. 4. Longitudinal section of the diaspores with small embryos (E) and perisperm (P). 5. Detail of the distal region of infructescense axis (micropyle), with residue of stigma (arrow). 6. Detail of the embryo showing the poles of differentiation of the cotyledons (PDC). 7. Details of the surface of the diaspores, with elevations like trichomes (arrow) and rectangular plates with defined contours, which resemble crystals $(\mathrm{Pc})$. Bar $=100 \mu \mathrm{m}(1-5) ; 20 \mu \mathrm{m}$ (6-7)

L. has a cordate embryo (Rosa \& Souza 2004) and $P$. parnassifolia, a globular embryo (Oliveira et al. 2008). The surface of the endocarp has grooves along its length (figure 1 and 7), sometimes covered with the remains of the mesocarp. Inside the grooves, one can verify the presence of numerous protrusions and wax plates (figure 6). This feature is remarkable and could be used in identification; however, it was not possible to compare with other species of Piper in view of the scarcity of studies. 
In the recently processed drupes, the moisture content was $24 \%$, but after drying it for 12 hours on a bench, it was reduced to $13 \%$. Proteins are the main class of chemical compound reserve in the diaspores (table 1), and because of that these can classified as proteic.

Table 1. Chemical constituents of the diaspores of Piper aduncum. Mean values in dry matter basis $\left(\mathrm{g}^{\left.100 \mathrm{~g}^{-1}\right) \text { and }}\right.$ standard deviation.

\begin{tabular}{llcc}
\hline Chemical compound & $\begin{array}{c}\text { \% in dry } \\
\text { matter basis } \\
\left(\mathrm{g} 100 \mathrm{~g}^{-1}\right)\end{array}$ & $\begin{array}{c}\text { Standard } \\
\text { Deviation }\end{array}$ \\
\hline & $\begin{array}{l}\text { Total reducing } \\
\text { sugars }\end{array}$ & 0.3276 & 0.0419 \\
Carbohydrate & Glucose & 0.1623 & 0.0204 \\
& Sucrose & 0.1573 & 0.0244 \\
& Starch & 1.8897 & 0.0235 \\
Gross protein & & 16.450 & 0.1750 \\
Ether extract & & 1.4601 & 0.1250 \\
Tannins & & 0.1064 & 0.0034 \\
\hline
\end{tabular}

We also observed the presence of tannins in drupes of $P$. aduncum. This compound has been associated with dormancy in Arabidopsis seeds (Nonogaki 2006), being speculated that its accumulation can improve the physical properties of the forehead, providing a mechanical strength that prevents radicle protrusion (Debeaujon \& Koornneef 2000). It has also been considered as a factor of dormancy, the influence of the chemical properties of tannins, such as its antagonistic function to that of gibberellins (Debeaujon et al. 2003). The high moisture content found in seeds is consistent with the presence of proteins as the predominant reserve compound, a fact that presumably could contribute to reduce the storage potential, due to the hydrophilic properties of this substance.

The characterization of the germination from early rupture of the endocarp up to the formation of the seedling is presented in figures 8-19. At 5 days after sowing (DAS), it was possible to visualize ruptures in the micropylar pole (figure 8), probably due to water absorption by the seed and also due to the development of the embryo. The radicle protrusion occurred at 7 DAS, with the seed coat surrounding it almost completely (figure 9 and 10). The seed coat is brownish, slightly honeycombed in aspect, as also observed by Vianna \& Akisue (1997). During germination, it was also possible to visualize the strong presence of endocarp containing trichomes (figure 11). At 9 DAS, the radicle was seen with the aid of a magnifying glass (figure 13), and only by scanning electromycrography it becomes clear the presence of numerous secondary roots (figure 12). The hypocotyledonary hook is formed at 12 DAS (figure 14 ) and at 13 DAS, it can be seen the greening of the cotyledons (figure 15). At 15 DAS, the cotyledons are still attached to the fruit (figure 16), detaching completely at 16 DAS (figure 17), resulting in a normal seedling. The cotyledons are photosynthetic and germination is epigeal, phanerocotylar, because the cotyledons arise from the substrate and free themselves completely from the integument, forming the seedling. At $20 \mathrm{DAS}$, the seedlings have about $1 \mathrm{~cm}$ length of shoot and root system, consisting of two cotyledons and developing Leaf primordia, with $0.00018 \mathrm{~cm}^{2}$ of total leaf area and $0.00015 \mathrm{~g}$ of total dry matter. We observed drupes containing two or three embryos, with the emergence of twin seedlings (figure 18), being one always of normal size and the others reduced, presenting at most 3 seedlings (figure 19). Unlike observed in this study, for several species of Piperaceae, only one embryo occurs, as reported by Vianna \& Akisue (1997), for P. aduncum, Rosa \& Souza (2004), for $P$. amalago var. medium, and Oliveira et al. (2008), for P. parnassifolia.

Regarding the physiological aspects of the drupes, submitted to different thermal and lighting conditions, regardless of the temperature, there was no germination in the dark and then one may consider the seeds as essentially positively photoblastic in the tested temperature range. These results corroborate those obtained by Rocha et al. (2005), that observed that seeds of $P$. aduncum, of two ecotypes (SP and PR), kept under extreme red light or dark, acquired induced dormancy, but subsequently germinated when exposed to red light. Germination of the diaspores that were not subjected to the dark occurred above $30^{\circ} \mathrm{C}$ and below $25^{\circ} \mathrm{C}$, but did not differ from those at $20-30{ }^{\circ} \mathrm{C}$. On the other hand, the IGS was higher at $30^{\circ} \mathrm{C}$ and lower at $20-30{ }^{\circ} \mathrm{C}$, not differing from diaspores germinated at $25^{\circ} \mathrm{C}$ (table 2). The results of this study are corroborated by Silva et al. (2007) who verified that diaspores, of a population of the same species in the Amazon region, subjected to regimes of $24^{\circ} \mathrm{C}, 27{ }^{\circ} \mathrm{C}$ and $30^{\circ} \mathrm{C}$, did not differ in the percentage and speed of germination.

Considering the post-germination process, of the diaspores that were not subjected to dark, one can observe that both the percentage and the speed of formation of normal seedlings were higher at $25^{\circ} \mathrm{C}$ and $30{ }^{\circ} \mathrm{C}$, not differing among them, although lower than at 20-30 ${ }^{\circ} \mathrm{C}$ (table 2). It is noteworthy that the differences between root protrusion and the seedlings formation were lower at $25^{\circ} \mathrm{C}$, indicating that this temperature 

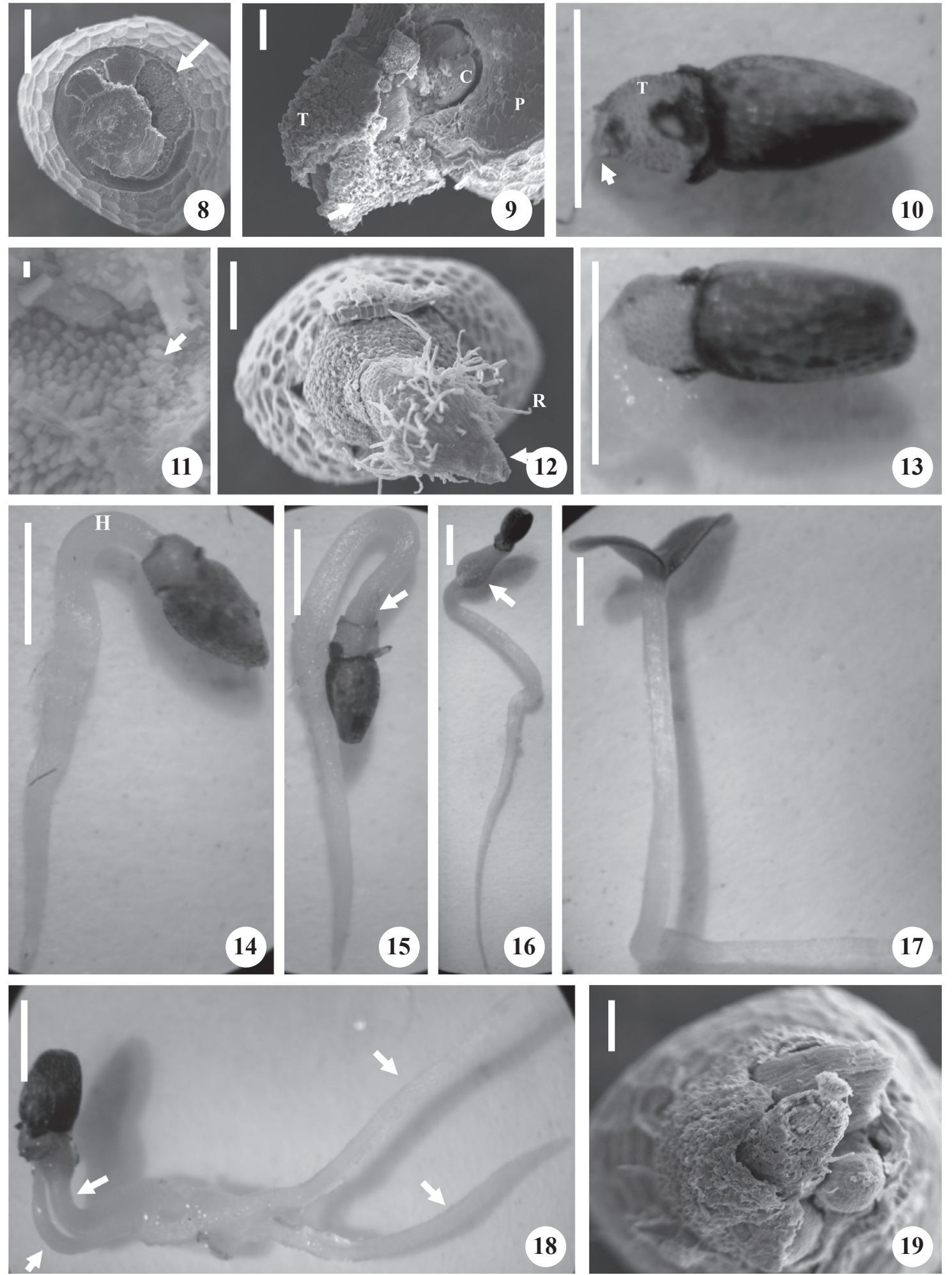

Figure 8-19. Electron scanning micrographs $(8,9,11,12$ and 19) and stereo-micrographs $(10,13,14-18)$ of the germination process of Piper aduncum. 8. Five days after sowing (DAS), showing cracks in the micropylar pole (arrow). 9 and 10. Seven DAS, rupture of the endocarp. 11. Details of the surface of the endocarp, with elevations (arrow). 12. Nine DAS, radicle protrusion. 13. Nine DAS, radicle protrusion. 14. Twelve DAS, formation of the hypocotyledonary hook. 15. Thirteen DAS, greening of the cotyledons. 16. Fifteen DAS, cotyledons detaching from the fruit. 17. Sixteen DAS, normal seedling. 18. Seedling still attached to the endocarp. 19. Protrusion of three radicles $(C=$ cotyledons; $T=$ tegument; $P=$ perisperm; $R$ $=$ secondary roots; $\mathrm{H}=$ hypocotyl). $\mathrm{Bar}=200 \mu \mathrm{m}(8) ; 100 \mu \mathrm{m}(9,19) ; 1 \mu \mathrm{m}(10,13-18) ; 2 \mu \mathrm{m}(11) ; 200 \mu \mathrm{m}(12)$. 
Table 2. Germination ( $\% \mathrm{G})$, index of germination speed (IGS), percentage of normal seedlings (\%S), index of normal seedlings formation speed (ISS) and the difference between root protrusion and formation of normal seedlings $(\% \mathrm{G}-\% \mathrm{~S})$ of Piper aduncum under different thermal regimes in the presence of light, without previous permanence hydrated in darkness for a month (no) and after permanence (yes).

\begin{tabular}{cccccrr}
\hline $\begin{array}{l}\text { Previous permanence } \\
\text { hydrated in darkness }\end{array}$ & $\begin{array}{c}\text { Temperature } \\
\left({ }^{\circ} \mathrm{C}\right)\end{array}$ & $\% \mathrm{G}$ & IGS & $\% \mathrm{~S}$ & $\mathrm{ISS}$ & $\% \mathrm{G}-\% \mathrm{~S}$ \\
\hline \multirow{3}{*}{ No } & 30 & $68 \mathrm{aA}$ & $4.72 \mathrm{aA}$ & $49 \mathrm{aA}$ & $2.19 \mathrm{aA}$ & $19 \mathrm{bA}$ \\
& $20-30$ & $59 \mathrm{abA}$ & $2.93 \mathrm{bA}$ & $15 \mathrm{bA}$ & $0.41 \mathrm{bB}$ & $44 \mathrm{aA}$ \\
& 25 & $49 \mathrm{bA}$ & $3.87 \mathrm{abB}$ & $45 \mathrm{aA}$ & $2.07 \mathrm{aB}$ & $4 \mathrm{cA}$ \\
\hline \multirow{2}{*}{ Yes } & 30 & $58 \mathrm{aA}$ & $5.10 \mathrm{bA}$ & $34 \mathrm{abB}$ & $1.81 \mathrm{bA}$ & $23 \mathrm{aA}$ \\
& $20-30$ & $51 \mathrm{aA}$ & $3.81 \mathrm{bA}$ & $26 \mathrm{bA}$ & $1.06 \mathrm{bA}$ & $26 \mathrm{aB}$ \\
& 25 & $53 \mathrm{aA}$ & $6.80 \mathrm{aA}$ & $49 \mathrm{aA}$ & $2.97 \mathrm{aA}$ & $4 \mathrm{bA}$ \\
\hline
\end{tabular}

* Means followed by same letter do not differ by Tukey test $(P<0.05)$. Lowercase letters compare the different thermal regimes in the diaspores that remained or not hydrated in the dark. Lowercase letters compare the diaspores that remained or not hydrated in the dark in each thermal regime.

favors the post-germination development. Based on the results obtained in this study, it can be concluded that although root protrusion is favored at $30^{\circ} \mathrm{C}$, the number of seedlings formed after root protrusion is impaired. According to Nonogaki (2006), the seed metabolism differs considerably during the germination and postgermination processes, especially in terms of gene expression profiles and desiccation tolerance, and thus the radicle emergence can be viewed as an important parameter of the seed development. Thus, it is possible that besides the differences in the metabolic processes during the germination and post-germination phases, responses to environmental conditions might also be different.

The diaspores that remained hydrated for a month in the dark, when put to germinate in the presence of light, showed a distinctive performance, compared to those that were not exposed to dark, in relation to thermal regimes (table 2). The germination did not differ with respect to tested thermal regimes, whereas the IGS and the percentage of normal seedlings were higher at $25^{\circ} \mathrm{C}$ and lower at $20-30{ }^{\circ} \mathrm{C}$. The speed of formation of normal seedlings were higher at $25^{\circ} \mathrm{C}$ and lower at $20-30{ }^{\circ} \mathrm{C}$ and $30^{\circ} \mathrm{C}$. In regards to the difference between root protrusion and seedling formation, it was verified that the smallest differences were also observed at $25^{\circ} \mathrm{C}$, however, it did not differ at $20-30{ }^{\circ} \mathrm{C}$ and $30{ }^{\circ} \mathrm{C}$.

When comparing the diaspores that remained or not for a month hydrated in the dark, the $\% \mathrm{G}$ did not differ (table 2). The IGS differed only for that diaspores germinated at $25^{\circ} \mathrm{C}$ and is higher in those who remained in the dark. The percentage of normal seedlings at $30{ }^{\circ} \mathrm{C}$ was lower in diaspores submitted to dark and the speed of seedling formation, was higher after exposure to dark at $25^{\circ} \mathrm{C}$ and $20-30{ }^{\circ} \mathrm{C}$.
Regarding the difference between root protrusion and seedling formation, it could be verified that at $20-30{ }^{\circ} \mathrm{C}$ occurred a diaspores reduction that were submitted to the dark. It can be concluded that permanence in the dark led to an increase in the speed of root protrusion, but mostly the percentage and speed of seedling formation were favored. These results corroborate those obtained by Rocha et al. (2005), that observed that for seeds of $P$. aduncum of two ecotypes (SP and PR) a higher percentage of germination occurred when the diaspores were exposed first to levels of saturation of extreme red, and, subsequently exposed to red light. To these authors, this species has a behavior consistent with the establishment in transition environments between the shade and direct sunlight (new deforested fields, gaps and borders of the forest) and recommend planting in the shade of other crops (15 to 20 days before harvest). In Arabidopsis seeds sensitive to light, the germination in the dark does not happen by a series of factors, including increased levels of ABA (Seo et al. 2009). In carrot seeds the embryo is immature and grows during the imbibition period before radicle protrusion. In the presence of $\mathrm{ABA}$, the radicle emergence is blocked, but embryo growth is promoted, suggesting that the degree of embryo development is controlled by ABA (Nonogaki 2006). We suggest that permanence in the dark may have promoted the development of the embryo.

The gibberellin was not able to reverse the positively photoblastic behavior of the diaspores of $P$. aduncum. Unlike the observed in this study, for some species the application of GA in seeds during imbibition replaces the requirement of light for germination. In these species, light can regulate the content of GA-modulated expression of genes encoding enzymes that participate in the biosynthesis and deactivation of GA (Sawada et 
al. 2008, Yamaguchi 2008, Seo et al. 2009). Perhaps the seeds of $P$. aduncum are not responsive to the application of $\mathrm{GA}_{3}$ but to other gibberellins, such as $\mathrm{GA}_{1}$ as in lettuce seeds (Sawada et al. 2008) or $\mathrm{GA}_{4}$ and $\mathrm{GA}_{7}$ as in seeds of Taxus mairei (Chien et al. 1998).

The application of $\mathrm{GA}_{3}$ negatively influenced the root protrusion of $P$. aduncum (figure 20). We observed a linear decrease in $\% \mathrm{G}$ and IGS, under increased concentration of $\mathrm{GA}_{3}$. For the seeds of Bertholletia excelsa Bonpl. the application of $\mathrm{GA}_{3}$ may have a negative effect on germination (Silva et al. 2009).

The formation of normal seedlings was not affected by the treatments; however, its length changed (figure $20 \mathrm{C}$ and D). The shoot length showed a quadratic behavior with the maximum value of $100 \mathrm{mg} \mathrm{L}^{-1}$ of $\mathrm{GA}_{3}$. Light induces photomorphogenesis, leading to inhibition of hypocotyl growth, whereas GAs promote etiolated growth characterized by increased hypocotyl elongation (Feng et al. 2008, Lucas et al. 2008). It is well established that GAs promote growth through the hypocotyl cell expansion, stimulating the destruction of DELLA proteins, which are known repressors of GA signaling (Feng et al. 2008, Ubeda-Tomás et al. 2008, Benková \& Hejátko 2009, Achard et al. 2009). Although GAs are strong stimulants of shoot growth, they not always accelerate root growth (Tanimoto 2005). In $P$. aduncum was observed a linear decrease in radicle length of normal seedlings with the addition of $\mathrm{GA}_{3}$ (figure 20C and D). In the roots of Arabidopsis, GA is an important regulator of growth, promoting both elongation (UbedaTomás et al. 2008) and cell proliferation (Achard et al. 2009, Ubeda-Tomás et al. 2009). GA levels seem to be necessary to promote and maintain the increase in the rate of root growth by controlling the size of the root meristem by means of mitotic activity (Ubeda-Tomas et al. 2009). However, the stimulus for the growth of roots requires the participation of other hormones such as auxins (Benková \& Hejátko 2009).

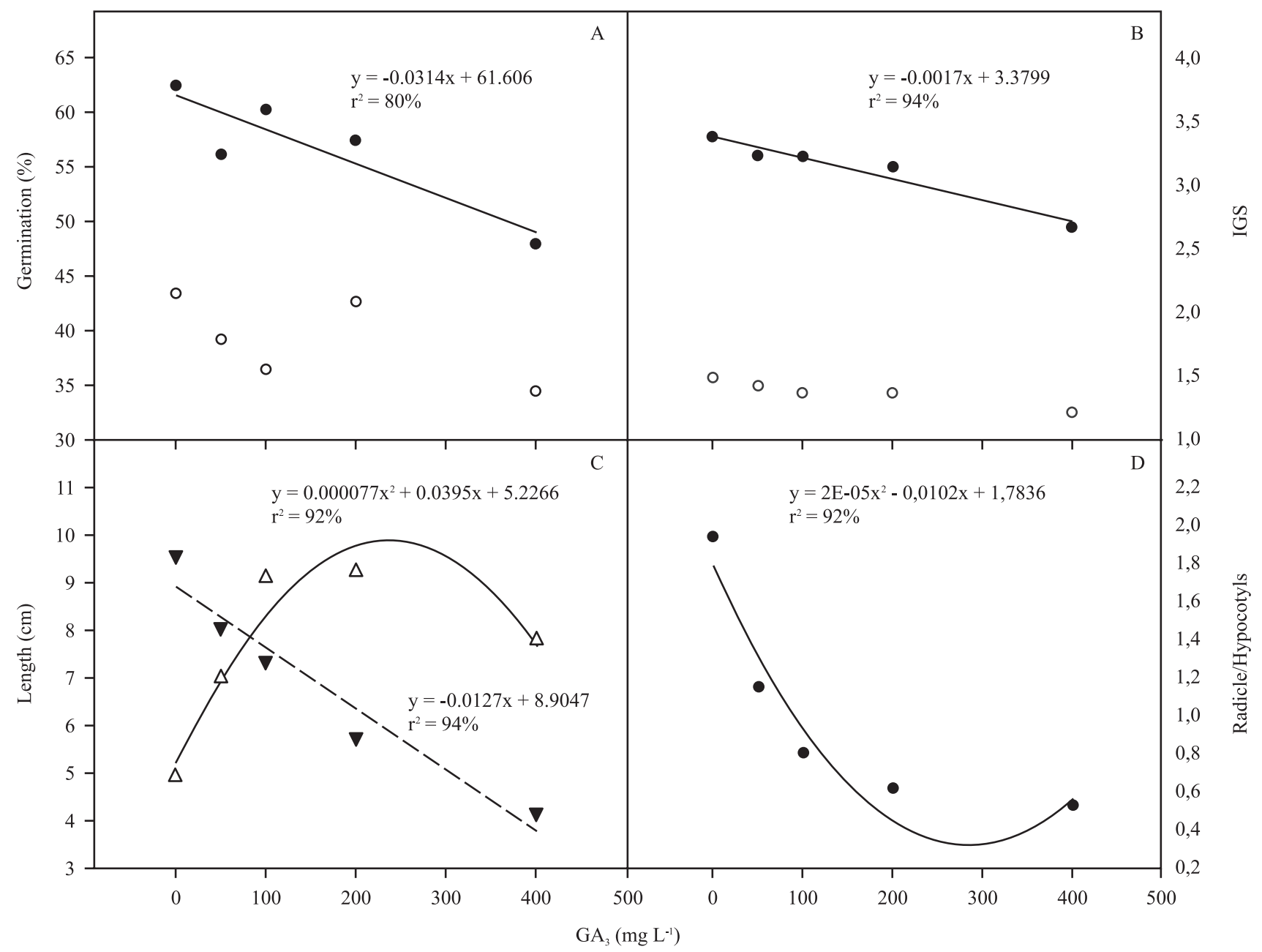

Figure 20. Germination and development of Piper aduncum seedlings, as a function of different concentrations of $\mathrm{GA}_{3}\left(\mathrm{mg} \mathrm{L}^{-1}\right)$. Germination- \%G (A). Index of germination speed- IGS (B). Comprimento das plântulas normais (C). Relação radícula/ hipocótilo (D). $(\bullet=$ radicle protrusion; $O=$ normal seedling; $\Delta=$ hypocotyl, $\nabla=$ radicle $)$. 
Acknowledgments - The authors would like to thank Capes for granting a Master's scholarship to the first author, and the laboratories of Plant Anatomy and Electron Microscopy and Ultra-structural Analysis of the Universidade Federal de Lavras for the technical and scientific support for the anatomical analysis.

\section{References}

ACHARD, P., GUSTI, A., CHEMINANT, S., ALIOUA, M., DHONDT, S., COPPENS, F., BEEMSTER, G.T.S. \& GENSCHIK, P. 2009. Gibberellin signaling controls cell proliferation rate in Arabidopsis. Current Biology 19:1188-1193.

ALVARENGA, A.P., BOTELHO, S.A. \& PEREIRA, I.M. 2006. Avaliação da regeneração natural na recomposição de matas ciliares em nascentes na região sul de Minas Gerais. Cerne 12:360-372.

AQÜILA, M.E.A. 2004. Tipos de diásporos e suas origens. In Germinação: do básico ao aplicado. (A.G. Ferreira, \& F. Borghetti, eds.) Artmed, Porto Alegre, p.69-92.

AOAC - Association Of Official Analytical Chemists. 1990. Official methods of analysis. $15^{\text {th }}$ ed. AOAC, Washington, v.2.

BASTOS, C.N. \& ALBUQUERQUE, P.S.B. 2004. Efeito do óleo de Piper aduncum no controle em pós-colheita de Colletotricum musae em banana. Fitopatologia Brasileira 29:555-557.

BENKOVÁ, E. \& HEJÁTKO, J. 2009. Hormone interactions at the root apical meristem. Plant Molecular Biology 69:383-396.

BRASIL. 2009a. Regras para análise de semente. Secretaria de Defesa Agropecuária - Mapa/ACS, Brasília.

BRASIL. 2009b. Glossário ilustrado de morfologia. Secretaria de Defesa Agropecuária - Mapa/ACS, Brasília.

CARVALHO, N.M. \& NAKAGAWA, J. 2000. Sementes: ciência, tecnologia e produção. $4^{\text {th }}$ ed. Funep, Jaboticabal.

CHIEN, C.T., KUO-HUANG, L.L. \& LIN, T.P. 1998. Changes in ultrastructure and abscisic acid level, and response to applied gibberellins in taxus mairei seeds treated with warm and cold stratification. Annals of Botany 81:41-47.

COCUCCI, A.E. \& MARIATH, J.E.A. 2004. Gameto gênese, fecundação, seleção do gametófito mais apto embriogênese e diásporo maduro. In Germinação: do básico ao aplicado. (A.G. Ferreira \& F. Borghetti, eds.). Artmed, Porto Alegre, p.15-30.

DEBEAUJON, I. \& KOORNNEEF, M. 2000. Gibberellin requirement for Arabidopsis seed germination is determined both by testa characteristics and embryonic abscisic acid. Plant Physiology 122:415-424.

DEBEAUJON, I., NESI, N., PEREZ, P., DEVIC, M., GRANDJEAN, O., CABOCHE, M. \& LEPINIEC, L. 2003. Proanthocyanidin-accumulating cells in Arabidopsis testa: regulation of differentiation and role in seed development. Plant Cell 15:2514-2531.
FAZOLIN, M., ESTRELA, J.L.V., CATANI, V., ALÉCIO, M.R. \& LIMA, M.S. DE. 2007. Propriedade inseticida dos óleos essenciais de Piper hispidinervum C. DC., Piper aduncum L. e Tanaecium nocturnum (Barb. Rodr.) Bur. \& K. Shum sobre Tenebrio molitor L., 1758. Ciência e Agrotecnologia 31:113-120.

FAZOLIN, M., ESTRELA, J.L.V., CATANI, V., LIMA, M.S. DE \& ALÉCIO, M.R. 2005. Toxicidade do óleo de Piper aduncum L. a adultos de Cerotoma tingomarianus Bechyné (Coleoptera: Chrysomelidae). Neotropical Entomology 34:485-489.

FENG, S., FENG, S., MARTINEZ, C., GUSMAROLI, G., WANG, Y., ZHOU, J., WANG, F., CHEN, L., YU, L., IGLESIAS-PEDRAZ, J.M., KIRCHER, S., SCHÄFER, E., FU, X., FAN, L.M. \& DENG, X. W. 2008. Coordinated regulation of Arabidopsis thaliana development by light and gibberellins. Nature 451:475-479.

FERREIRA, D.F. 1999. SISVAR: sistema de análises estatísticas. versão 4.3. Universidade Federal de Lavras, Lavras.

FIDALGO, L.M., RAMOS, I.S., ALVAREZ, A.M.M., LORENTE, N.G., LIZAMA, R.S. \& PAYROL, J.A. 2004. Propiedades antiprotozoarias de aceites esenciales extraídos de plantas cubanas. Revista Cubana de Medicina Tropical 56:230-233.

FRANKLIN, K.A. 2009. Light and temperature signal crosstalk in plant development. Current Opinion in Plant Biology 12:63-68.

GARCÍA-MARTINEZ, J.L. \& GIL, J. 2001. Light regulation of gibberellin biosynthesis and mode of action. Journal Plant Growth Regulation 20:354-368.

GUERRINI, A., SACCHETTI, G., ROSSI, D., PAGANETTO, G., MUZZOLI, M., ANDREOTTI, E., TOGNOLINI, M., MALDONADO, M.E. \& BRUNI, R. 2009. Bioactivities of Piper aduncum L. and Piper obliquum Ruiz \& Pavon (Piperaceae) essential oils from Eastern Ecuador. Environmental Toxicology and Pharmacology 27:39-48.

HESCHEL, M.S., SELBY, J., BUTLER, C., WHITELAM, G.C., SHARROCK, R.A. \& DONOHUE, K. 2007. A new role for phytochromes in temperature-dependent germination. New Phytologist 174:735-741.

JUSTO, C.F., ALVARENGA, A.A. DE, ALVES, E., GUIMARÃES, R.M., STRASSBURG, R.C. 2007. Efeito da secagem, do armazenamento e da germinação sobre a micromorfologia de sementes de Eugenia pyriformis Camb. Acta Botanica Brasilica 21:539-551.

LORENZI, H. \& MATOS, F.J.A. 2002. Plantas medicinais no Brasil: nativas e exóticas cultivadas. Instituto Plantarum, Nova Odessa.

LUCAS, M. DE, DAVIÈRE, J.M., RODRÍGUEZ-FALCÓN, M., PONTIN, M., IGLESIAS-PEDRAZ, J.M., LORRAIN, S., FANKHAUSER, C., BLÁZQUEZ, M.A., TITARENKO, E. \& PRAT, S.A. 2008. Molecular framework for light and gibberellin control of cell elongation. Nature 451:480-484. 
MAGUIRE, J.D. 1962. Speed of germination-aid in selection and evaluation for seedling emergence and vigour. Crop Science 2:176-177.

MILBERG, P., ANDERSSON, L. \& THOMPSON, K. 2000. Large-seeded species are less dependent on light for germination than small-seeded ones. Seed Science Research 10:99-104.

NAVICKIENE, H.M.D., MORANDIM, A. DE A., ALÉCIO, A.C., REGASINI, L.O., BERGAMO, D.C.B., TELASCREA, M., CAVALHEIRO, A.J., LOPES, M.N., BOLZANI, V. DA S., FURLAN, M., MARQUES, M.O.M., YOUNG, M.C.M. \& KATO, M.J. 2006. Composition and antifungal activity of essential oils from Piper aduncum, Piper arboreum and Piper tuberculatum. Química Nova 29:467-470.

NELSON, N.A. 1944. A photometric adaptation of Somogy method for determination of glucose. Journal of Biological Chemistry 153:375-390.

NONOGAKI, H. 2006. Seed Germination - The biochemical and molecular mechanisms. Breeding Science 56: 93-105.

OLIVEIRA, J.H.G. DE, SOUZA, L.A. DE \& IWAZAKI, M. DE C. 2008. Estruturas de reprodução de Peperomia parnassifolia Miq. (Piperaceae). Acta Scientiarum Biological Sciences 30:1-7.

PEARSON, T.R.H., BURSLEM, D.F.R.P., MULLINS, C.E. \& DALLING, J.W. 2003. Functional significance of photoblastic germination in neotropical pioneer trees: a seed's eye view. Funtional Ecology 17:394-402.

PENFIELD, S. 2008. Temperature perception and signal transduction in plants. New Phytologist 179:615-628.

PEREIRA, A.C.R.L., OLIVEIRA, J.V. DE, GONDIM JÚNIOR, M.G.C. \& CÂMARA, C.A.G. DA 2008. Atividade inseticida de óleos essenciais e fixos sobre Callosobruchus maculatus (FABR., 1775) (Coleoptera: Bruchidae) em grãos de caupi [Vigna unguiculata (L.) Walp.]. Ciência e Agrotecnologia 32:717-724.

ROCHA, S.F.R., MING, L.C., CHAVES, F.C.M. \& SCARDA, F.M. 2005. Role of light and phytochrome on Piper aduncum L. germination: an adaptive and environmental approach. Journal of Herbs, Spices \& Medicinal Plants 11:85-96.

ROSA, S.M. DA \& SOUZA, L.A. DE. 2004. Estruturas de reprodução de Piper amalago var. medium Linnaeus (Piperaceae). Acta Cientifica Venezolana 55:27-34.

SAWADA, Y., AOKI, M., NAKAMINAMI, K., MITSUHASHI, W., TATEMATSU, K., KUSHIRO, T., KOSHIBA, T., KAMIYA, Y., INOUE, Y., NAMBARA, E. \& TOYOMASU, T. 2008. Phytochrome- and gibberellin-mediated regulation of abscisic acid metabolism during germination of photoblastic lettuce seeds. Plant Physiology 146:1386-1396.

SEO, M., NAMBARA, E., CHOI, G. \& YAMAGUCHI, S. 2009. Interaction of light and hormone signals in germinating seeds. Plant Molecular Biology 69:463-472.
SILVA, A.N. DA, COELHO, M. DE F.B., GUIMARÃES, S.C. \& ALBUQUERQUE, M.C. DE F.E. 2009. Germinação de sementes de castanheira-do-pará armazenadas em areia úmida. Pesquisa Agropecuaria Brasileira 44: 1431-1436.

SILVA, G.M. DA C., SILVA, H., ALMEIDA, M.V.A. DE, CAVALCANTI, M.L.F. \& MARTINS, P. DE L. 2003. Morfologia do fruto, semente e plântula do Mororó (ou pata de vaca) - Bauhína forficata Linn. Revista de Biologia e Ciências da Terra 3:1-16.

SILVA, M.H.L. DA, COSTA, R.C.L., LOBATO, A.K. DA S., OLIVEIRA NETO, C.F. DE \& LAUGHINGHOUSE, D.H. 2007. Effect of temperature and water restriction on Piper aduncum L. seed germination. Journal of Agronomy 6:472-475.

SOCOLOWSKI, F., VIEIRA, D.C.M. \& MASSANORI, T. 2008. Interaction of Temperature and Light on Seed Germination in Tecoma stans L. Juss. ex Kunth (Bignoniaceae). Brazilian Archives of Biology and Technology 51:723-730.

SOUSA, P.J.C., BARROS, C.A.L., ROCHA, J.C.S., LIRA, D.S., MONTEIRO, G.M. \& MAIA, J.G.S. 2008. Avaliação toxicológica do óleo essencial de Piper aduncum L. Revista Brasileira de Farmacognosia 18:217-221.

TANIMOTO, E. 2005. Regulation of root growth by plant hormones - roles for auxin and gibberellin. Critical Reviews in Plant Sciences 24:249-265.

TOH, S., IMAMURA,A., WATANABE,A., NAKABAYASHI, K., OKAMOT, M., JIKUMARU, Y., HANADA, A., ASO, Y., ISHIYAMA, K., TAMURA, N., IUCHI, S., KOBAYASHI, M., YAMAGUCHI, S., KAMIYA, Y., NAMBARA, E. \& KAWAKAMI, N. 2008. High temperature-induced abscisic acid biosynthesis and its role in the inhibition of gibberellin action in Arabidopsis seeds. Plant Physiology 146: 1368-1385.

UBEDA-TOMÁS, S., SWARUP, R., COATES, J., SWARUP, K., LAPLAZE, L., BEEMSTER, G.T., HEDDEN, P., BHALERAO, R. \& BENNETT, M.J. 2008. Root growth in Arabidopsis requires gibberellin/DELLA signalling in the endodermis. Nature Cell Biology 10: 625-628.

UBEDA-TOMÁS, S., FEDERICI, F., CASIMIRO, I., BEEMSTER, G.T.S., BHALERAO, R., SWARUP, R., DOERNER, P., HASELOFF, J. \& BENNETT, M. J. 2009. Gibberellin signaling in the endodermis controls Arabidopsis Root Meristem Size. Current Biology 19:1194-1199.

VIANNA, W.O. \& AKISUE, G. 1997. Caracterização morfológica de Piper aduncum L. Lecta 15:11-62.

YAMAGUCHI, S. 2008. Gibberellin metabolism and its regulation. Annual Review of Plant Biology 59:225-251. 
